\section{Principles and Practices of Foliar Nutrients with an Emphasis on Nitrogen and Calcium Sprays in Apple}

\author{
Esmaeil Fallahi ${ }^{1,3}$ and Thomas Eichert ${ }^{2}$
}

AdDitional INDEX wORDs. Malus domestica, mineral nutrition, supplementary nutrients, uptake mechanism, urea spray

SUMMARY. Foliar fertilization is a common practice to supply crops with mineral nutrients, especially under limited soil nutrient availability conditions. However, foliar-applied nutrients have to overcome the barrier properties of leaf surface to be absorbed by plants. Various pathways are reported to explain the penetration of foliar nutrients through the leaf tissues. Meanwhile, we believe that air humidity is one of the main controlling factors in this process since it controls both the actual nutrient concentration on the leaf surface as the driving force of absorption and the permeability of the leaf surface. Postharvest and prebloom foliar nitrogen sprays are applied to enhance flower bud vigor, and calcium $(\mathrm{Ca})$ is applied directly to fruit during the growing season to reduce fruit susceptibility to physiological disorders. Micronutrients typically are applied in foliar sprays to uniformly distribute the small quantities of these required nutrients. In this report, we focus on the principles of foliar nutrient uptake and impacts of foliar urea and Ca sprays on fruit quality attributes of 'Fuji' apples (Malus domestica). Based on our studies, a ground application of urea is critical for a higher production of 'Fuji' apple.

$\mathrm{D}$ eciduous tree fruit yield and quality will suffer in response to insufficiency of any mineral nutrient and foliar applications of some elements, including nitrogen $(\mathrm{N})$, calcium, potassium $(\mathrm{K})$, and boron (B), that are closely tied to fruit quality. Macronutrient and micronutrient sprays are typically supplementary to soil applications and applied to quickly alleviate nutrient deficiencies that appear suddenly, such as those induced by excessive vegetative growth or nutrient imbalances caused by improper applications of fertilizers or soil amendments. Micronutrients are required and applied in small quantities but are essential for various biochemical and physiological processes of plant growth and development (Swietlik and Faust, 1984). Recent research focuses on developing foliar spray programs that enhance nutrient phytoavailability, thereby reducing nutrient requirements and minimizing release of potentially deleterious elements into the environment, and that allow safe tank-mixing of multiple

${ }^{1}$ Professor and Director of Pomology Program, Parma Research and Extension Center, University of Idaho, 29603 U of I lane, Parma, ID 83660

${ }^{2}$ Institute of Crop Science and Resource Conservation (INRES), Department of Plant Nutrition, University of Bonn, Karlrobert-Kreiten-Street 13, 53115 Bonn, Germany

${ }^{3}$ Corresponding author. E-mail: efallahi@uidaho.edu. nutrients, which would reduce the number of sprays required per season (Peryea et al., 2003).

It is important to understand the basic physiology of foliar nutrient uptake through the cuticle to develop a more efficient and successful foliar nutrition program in tree fruit. Thus, this article focuses on two aspects of foliar nutrition: 1) potential mechanism and controlling factors of foliar nutrient uptake and 2) practical aspects of foliar nutrition with an emphasis on $\mathrm{N}$ and Ca sprays in 'Fuji' apple.

\section{Penetration of foliar nutrients}

Foliar fertilization is a common practice to supply crops with mineral nutrients, especially under conditions of limited soil nutrient availability or in the case of acute deficiency. However, aerial plant parts are designed to minimize exchange of water with the environment rather than to absorb mineral nutrients. For this purpose, leaf surfaces are equipped with a water repellent lipophilic cuticle which presents a high resistance against the penetration of hydrophilic solutes such as mineral nutrients. Moreover, stomata are protected against the infiltration of liquid water (Schonherr and Bukovac, 1972). Foliar-applied nutrients thus have to overcome the barrier properties of leaf surfaces to be absorbed by leaves (Eichert and Fernandez, 2012).

A specific feature of leaf penetration by mineral nutrients is that, contrary to root uptake, no active processes are involved and hence nutrient penetration of leaf surfaces is not selective. The passive nature of the uptake process has an important consequence: any substance present on the leaf surface will penetrate the leaf surface as long as there is a concentration gradient across the leaf surface as the driving force of diffusion. If the resulting penetration rates are too high and incompatible with the plant's metabolism, leaf damage ("leaf scorch") will accrue. This phenomenon can often be observed in field applications. The efficacy of foliar sprays is thus challenged by both, low uptake rates because of the barrier properties of leaf surfaces and potentially excessive uptake because of the nondiscriminatory passive uptake process. Hence, the main challenge of foliar sprays is to apply the optimum nutrient dose which corrects or prevents nutrient deficiency without causing leaf scorch.

Foliar uptake rates are not only controlled by the resistance of the leaf surface but also by the nutrient

\begin{tabular}{llll}
\hline $\begin{array}{l}\text { Units } \\
\begin{array}{l}\text { To convert U.S. to SI, } \\
\text { multiply by }\end{array}\end{array}$ & U.S. unit & SI unit & $\begin{array}{l}\text { To convert SI to U.S., } \\
\text { multiply by }\end{array}$ \\
\hline 29.5735 & $\mathrm{fl} \mathrm{oz}$ & $\mathrm{mL}$ & 0.0338 \\
0.3048 & $\mathrm{ft}$ & $\mathrm{m}$ & 3.2808 \\
3.7854 & $\mathrm{gal}$ & $\mathrm{L}$ & 0.2642 \\
9.3540 & $\mathrm{gal} / \mathrm{acre}$ & $\mathrm{L} \cdot \mathrm{ha}^{-1}$ & 0.1069 \\
6.4516 & inch & $\mathrm{cm}^{2}$ & 0.1550 \\
0.4536 & $\mathrm{lb}$ & $\mathrm{kg}$ & 2.2046 \\
0.0703 & $\mathrm{lb} / \mathrm{inch}^{2}$ & $\mathrm{~kg} \cdot \mathrm{cm}^{-2}$ & 14.2233 \\
4.4482 & $\mathrm{lbf}$ & $\mathrm{N}$ & 0.2248 \\
28.3495 & $\mathrm{oz}$ & $\mathrm{g}$ & 0.0353 \\
7.4892 & $\mathrm{oz} / \mathrm{gal}^{2}$ & $\mathrm{~g} \cdot \mathrm{L}^{-1}$ & 0.1335 \\
1 & $\mathrm{ppm}$ & $\mathrm{mg} \cdot \mathrm{kg}^{-1}$ & 1 \\
0.4732 & $\mathrm{pt}$ & $\mathrm{L}$ & 2.1134 \\
$\left({ }^{\circ} \mathrm{F}-32\right) \div 1.8$ & ${ }^{\circ} \mathrm{F}$ & ${ }^{\circ} \mathrm{C}$ & $\left({ }^{\circ} \mathrm{C} \times 1.8\right)+32$ \\
& & & \\
\hline
\end{tabular}


concentration on the leaf. The solute concentrations in foliar sprays are in most cases initially not in equilibrium with the humidity of atmosphere. As a consequence, spray solutions will evaporate until this equilibrium is reached. It has been shown that the equilibrium concentrations of foliarapplied solutes present on the leaf surface depend on both the ambient relative humidity ( $\mathrm{RH})$ and the hygroscopicity of the solute (Fernandez and Eichert, 2009). The degree of hygroscopicity of a solute can be defined by the RH above which the salt dissolves in the water absorbed from the atmosphere. This threshold humidity is called "deliquescence relative humidity" (DRH) or "deliquescence point." The interaction between $\mathrm{RH}$ and DRH of the solute determines whether the spray solution will crystallize on the leaf surface (if RH < $\mathrm{DRH}$ ) or stay in solution (if $\mathrm{RH}>$ DRH) (Eichert and Fernandez, 2012; Fernandez and Eichert, 2009).

The pathways by which foliarapplied solutes penetrate leaf surface have been a matter of debate for a long time. One of the first concepts discussed in literature were "ectodesmata" (Eichert and Fernandez, 2012). They were believed to be specific structures in the cuticle designed for foliar uptake of hydrophilic solutes such as nutrient salts (Franke, 1960, 1964; Schumacher and Lambertz, 1956). This concept was later revoked (Schonherr, 2006; Schonherr and Bukovac, 1970) but still circulates in textbooks and reviews. While some research groups regarded the role of stomata as negligible (Schonherr and Bukovac, 1972) and thus focused on the cuticle (e.g., Schonherr, 1976, 2000 ), others provided evidence that leaf-applied chemicals may use the stomatal route for penetration (Eichert and Burkhardt, 2001; Eichert et al., 2008). It is now established that these two pathways, stomata and the cuticle, act in parallel, but their relative importance will depend on the properties of the foliar-applied solute (Eichert and Fernandez, 2012). Relative humidity not only regulates the concentration of applied nutrients on the leaf surface as described above but also affects the permeability of the leaf surface by modifying the aperture of stomata and the hydration state of the cuticle. However, the functional relationship between $\mathrm{RH}$ and leaf permeability is still not fully understood (Fernandez and Eichert, 2009).

The increased theoretical knowledge on the principles of foliar penetration has some implications for the practical use of foliar application of mineral nutrients on fruit trees. Since many plant species, such as fruit trees, lack stomata on the upper leaf side, maximum uptake rates of foliarapplied nutrients can only be achieved if the lower leaf sides are sprayed as well. Furthermore, knowledge on the deliquescence properties of the applied salts may enable us to more accurately control the uptake rate and recovery of foliar-applied nutrients. Salts with a low DRH such as calcium chloride $\left(\mathrm{CaCl}_{2}\right)$ tend to remain in solution and can thus be efficiently absorbed by leaves even if RH is low, leading to high uptake efficiency or recovery. If on the other hand, fast absorption has to be avoided to reduce the risk of leaf scorch, salts with a high DRH can be selected. Nitrogen, for example, is often sprayed in comparably high concentrations, and the resulting high $\mathrm{N}$ doses on the leaf surface would induce scorch if absorbed in too high rates. Therefore, foliar $\mathrm{N}$ application compounds with rather high DRH values, such as urea, should be selected when the environmental conditions such as $\mathrm{RH}$ and temperature permit (Eichert and Fernandez, 2012).

\section{Practical foliar applications of $\mathrm{N}$ and $\mathrm{Ca}$}

Calcium and $\mathrm{N}$ are the most important and commonly used elements applied through foliar applications in tree fruit, including apple. In the past decades, a number of new apple cultivars were introduced to the apple market, among which, 'Fuji' has gained high popularity. However, limited information is available on the effects of foliar urea on 'Fuji' apple growth, yield, and fruit quality.

The principal mechanism and practical applications of urea in 'Washington' navel orange (Citrus sinensis) and 'Hass' avocado (Persea americana) have been extensively studied by Lovatt and Cheng (1990) and Lovatt (1999). Urea has been foliarly applied effectively on 'McIntosh' apple trees in the eastern United States (Blasberg, 1953; Fisher, 1952; Shim et al., 1972). Fisher (1952) reported that trees receiving three foliar urea applications had a similar yield as those with a similar amount of $\mathrm{N}$ applied to the soil. Forshey (1963) reported that only two-thirds of the $\mathrm{N}$ applied as foliar urea sprays were absorbed, while most of those added to soil was taken up by 'McIntosh' apple trees. In that report, leaf minerals other than $\mathrm{N}$ also were affected by both amount and method of urea application (Forshey, 1963).

The effectiveness of springapplied foliar urea sprays for fruit trees is controversial. Some researchers have reported that foliar urea applied in the spring is equally or more effective than soil $\mathrm{N}$ applications in improving fruit set and subsequent fruit size and yield (Blasberg, 1953; Fisher and Cook, 1950). Others have found that the effects of this practice are largely confined to the sprayed leaves and do not affect fruiting or the $\mathrm{N}$ status of the entire tree (Forshey, 1963). Sanchez et al. (1990) suggested that $\mathrm{N}$ moving into expanding pear (Pyrus communis) leaves is used to build cell structure rather than being incorporated into enzymes or storage compounds. Structural N may be more difficult to remobilize than $\mathrm{N}$ that accumulates in leaves later in the season (Khemira et al., 1998). Since Oland (1960) first introduced the use of autumn urea sprays to increase the $\mathrm{N}$ reserves of apple trees, a considerable amount of literature has accumulated on the subject (O'Kennedy et al., 1975; Sanchez et al., 1990; Shim et al., 1972; Williams, 1965).

\section{Foliar urea and $\mathrm{Ca}$ experiments with apples in Idaho Materials and methods}

MATERIALS AND METHODS FOR FOLIAR UREA APPLICATIONS. An extensive experiment was undertaken to study the influence of foliar and ground urea application on tree growth and fruit quality of 'Fuji' apple. The experimental orchard was located at the University of Idaho Parma Research and Extension Center, Parma. 'BC-2 Red Fuji' apples on M.9 (M.9 NAKBT337), M.26 East Malling-Long Ashton (M.26 EMLA), and M.7 East MallingLong Ashton (M.7 EMLA) were planted at $8 \times 16$ - $\mathrm{ft}$ spacing on a sandy loam soil with a $\mathrm{pH}$ of 7.5 in Spring 2006. The orchard was irrigated using a sprinkler system.

Experimental $\mathrm{N}$ treatments started in 2008. Nitrogen was applied in four 
treatments as three rates of urea $(46 \%$ $\mathrm{N}$ ) as multiple foliar sprays (Sprayl, Spray2, and Spray3) and one rate of ground-applied urea in two split ground applications in each year during 2008-10. The rate in the ground application was similar to the lowest rate that is commonly applied to young apple trees in the Pacific northwestern United States. At each application time during 2008, trees were sprayed to the drip point with urea dissolved in water, at one of the following rates: $3.2 \mathrm{~g} \cdot \mathrm{L}^{-1}$ urea (Sprayl), $9.6 \mathrm{~g} \cdot \mathrm{L}^{-1}$ urea (Spray2), or $16.0 \mathrm{~g} \cdot \mathrm{L}^{-1}$ urea (Spray3). Spray3 caused minor leaf burning in 2008. At each spray time during 2009 and 2010 , the foliar treatments were: $1.6 \mathrm{~g} \cdot \mathrm{L}^{-1}$ urea (Sprayl), $4.8 \mathrm{~g} \cdot \mathrm{L}^{-1}$ urea (Spray2), or $8.01 \mathrm{~g} \cdot \mathrm{L}^{-1}$ urea (Spray3). These rates provided $\approx 0.8,2.3$, and $3.9 \mathrm{~g}$ of actual $\mathrm{N}$ per tree at each spray application. Spray3 treatment was at the maximum rate beyond which leaves would be injured. In 2008, the foliar applications were made on 1 July, 1 Aug., and 1 Sept. In 2009 and 2010, foliar applications started at full bloom (5 May 2009 and 3 May 2010) and continued once per month until September (total of five sprays each year). In the ground treatment, urea was applied to the soil in a 2 - $\mathrm{ft}$ radius around the tree trunk at the rate of $29.6 \mathrm{~g}$ per tree in each of two applications in 2008 ( 3 June and 7 July; total of $59.2 \mathrm{~g}$ urea per tree). To establish the one rate ground-applied urea treatment, two ground applications of $34.5 \mathrm{~g}$ urea per tree were made in a 2.5 -ft radius around the trunk in each split-spring application in 2009 (14 May and 20 June) and 2010 (21 Apr. and 7 June) to provide a total of 69 $\mathrm{g}$ urea per tree per year in 2009 and 2010. Other cultural practices were similar to those of commercial 'Fuji' orchards in the region for tree fruit in Washington (Washington State University, 2013). The experimental design was a randomized-complete-block split-plot design, with three rootstocks as main plots, four $\mathrm{N}$ treatments as subplots, and five blocks. Within each block, a single tree was used for each rootstock-nitrogen combination. Each treatment was protected with at least two guard trees.

Trunk cross-sectional area (TCA) was calculated from trunk diameter 6 inches above the bud union in late February in 2008-11. Yield was recorded and yield efficiency was calculated as kilograms per square centimeter of TCA. Thirty-four fruit from each tree were picked randomly at commercial harvest (17 Oct. 2010). Fruit were divided into two groups, weighed, and placed in perforated polyethylene bags. Fruit from one bag were tested for various quality attributes at harvest and fruit of the other bag were used for poststorage analyses. Fruit color was rated visually on a scale from $1=$ lowest red color progressively to $5=100 \%$ pinkish-red. Fruit firmness was measured on three peeled sides of each fruit by a penetrometer (Facchini, Alfonsine, Italy). Fruit were then cut equatorially. One wedge from the calyxend half of every fruit was juiced and the soluble solids concentration (SSC) was measured. The stem-end half of the fruit at harvest was dipped in iodine solution (containing potassium iodide and iodine crystals dissolved in water) and the starch degradation pattern (SDP) for each fruit at harvest was recorded. Thirty leaves per tree were sampled randomly from the middle of the current-season's shoot in mid-August of 2009 and 2010. Leaves were washed, dried, ground, and analyzed for $\mathrm{N}$ by the micro-Kjeldahl method (Schuman et al., 1973) and for K, Ca, magnesium $(\mathrm{Mg}), \mathrm{Fe}$, zinc $(\mathrm{Zn})$, manganese $(\mathrm{Mn})$, and copper $(\mathrm{Cu})$ by dry ashing at $500{ }^{\circ} \mathrm{C}$, digestion, and atomic absorption spectrophotometery (B1100; PerkinElmer, Norwalk, CT) as described by Chaplin and Dixon (1974) and Jones (1977). Analyses of variance were conducted by SAS (version 9.1; SAS Institute, Cary, NC), and means were compared by least significant difference at 0.05 .

MATERIALS AND METHODS FOR FOLIAR CALCIUM APPLICATION. The experimental 'Top Export Fuji' trees on 'RN.29' rootstock were planted at $5 \times$ 14-ft spacing at the University of Idaho Parma Research and Extension Center in Spring and early Summer 2002. Soil conditions, tree training, and cultural practices, other than $\mathrm{Ca}$ treatments, were similar to those described earlier for urea experiment. Two formulations of commercial foliar Ca fertilizers were sprayed at different frequencies during 2011. These formulations included calcium chloride $\left(\mathrm{CaCl}_{2}\right)$ and chelated calcium (Metalostae Calcium; Albion Laboratories, Clearfield, UT). Chelated calcium was an amino acid-based liquid fertilizer with $6 \%$ chelated Ca. Treatments were as follows: 1) untreated control; 2) chelated calcium $5 \mathrm{x}, \mathrm{CaCl}_{2} 3 \mathrm{x}$ where chelated calcium was applied five times, beginning with the early petal fall stage and continued during growing season, and $\mathrm{CaCl}_{2}$ at $0.36 \%$ was applied three times during the growing season; 3 ) chelated calcium $5 x$, where chelated calcium was applied five times, beginning at the early petal fall stage and continued during growing season; 4) chelated calcium $4 x$, $\mathrm{CaCl}_{2} 3 \mathrm{x}$ where chelated calcium was applied four times, beginning at the late petal fall stage and continued during the growing season, and $\mathrm{CaCl}_{2}$ at $0.36 \%$ was also sprayed three times; 5 ) $\mathrm{CaCl}_{2} 3 \mathrm{x}$ is the trees received $\mathrm{CaCl}_{2}$ at $0.36 \%$ three times.

In each treatment containing chelated calcium, 1.25 pt of this chemical and $5 \mathrm{fl} \mathrm{oz}$ of surfactant [alkylphenol ethoxylate, butyl alcohol, dimethylpolysiloxane 90\% (R-11; Wilbur-Ellis, Fresno, CA)] were mixed in $100 \mathrm{gal}$ of water and the solution was sprayed at a rate of $200 \mathrm{gal} / \mathrm{acre}$ with a handgun sprayer. Each application of $\mathrm{CaCl}_{2}$ consisted of $6 \mathrm{lb}$ of $\mathrm{CaCl}_{2}$ in $200 \mathrm{gal}$ and sprayed at a rate of 200 gal/acre with an air-blast sprayer. Fruit yield and quality attributes were measured as described earlier for urea applications.

\section{Results and discussion}

RESUlTS AND DISCUSSION FOR UREA APPLICATIONS. There was no interaction between rootstocks and $\mathrm{N}$ treatments for any parameter measured and thus, results over the three rootstocks were pooled and only results for the $\mathrm{N}$ treatments are reported here. Trunk cross-sectional areas of all trees were similar before treatment in 2008 (Table 1). In 2009 and 2010 (1 and 2 years after the beginning of $\mathrm{N}$ treatments, respectively), trees in the ground treatment had higher TCA than other treatments (Table 1). In 2011 , differences in TCA among treatments were not significant (Table 1). Yield per tree and yield efficiency in the ground treatment were significantly greater than those with foliar $\mathrm{N}$ sprays (Table 1). Fruit from trees with ground and Spray3 treatments were heavier (larger) than those of Sprayl and Spray 2 treatments because both ground and Spray3 had similar levels of leaf $\mathrm{N}$, and these levels tended to be greater than those of Sprayl and Spray2 in 2010 (Table 2). 
Table 1. Effects of urea nitrogen treatments on tree growth, yield per tree, yield efficiency, fruit weight, and firmness of 'BC-2 Fuji' apple on three rootstocks.

\begin{tabular}{|c|c|c|c|c|c|c|c|c|c|}
\hline \multirow{2}{*}{$\begin{array}{l}\text { Nitrogen } \\
\text { regime }^{z}\end{array}$} & \multicolumn{4}{|c|}{ Trunk cross-sectional area $\left(\mathrm{cm}^{2}\right)^{\mathrm{y}}$} & \multirow{2}{*}{$\begin{array}{l}\text { Yield } 2010 \\
(\mathrm{~kg} / \text { tree })^{\mathrm{y}}\end{array}$} & \multirow{2}{*}{$\begin{array}{l}\text { Yield efficiency } \\
\qquad\left(\mathrm{kg} \cdot \mathrm{cm}^{-2}\right)^{x}\end{array}$} & \multirow{2}{*}{$\begin{array}{c}\begin{array}{c}\text { Fruit } \\
\text { wt }(g)^{\mathrm{z}}\end{array} \\
\end{array}$} & \multicolumn{2}{|c|}{ Firmness $(\mathbf{N})^{\mathrm{y}}$} \\
\hline & 2008 & 2009 & 2010 & 2011 & & & & Harvest & Storage \\
\hline Sprayl & $3.3 \mathrm{a}^{\mathrm{z}}$ & $6.5 \mathrm{~b}$ & $15.1 \mathrm{~b}$ & $26.9 \mathrm{a}$ & $9.3 \mathrm{~b}$ & $0.37 \mathrm{~b}$ & $238 \mathrm{~b}$ & $90.3 \mathrm{a}$ & $79.7 \mathrm{a}$ \\
\hline Spray3 & $3.0 \mathrm{a}$ & $6.2 \mathrm{~b}$ & $16.3 \mathrm{~b}$ & $28.3 \mathrm{a}$ & $7.5 \mathrm{~b}$ & $0.33 \mathrm{~b}$ & $277 \mathrm{a}$ & $87.3 \mathrm{ab}$ & $74.5 \mathrm{ab}$ \\
\hline Ground & $3.3 \mathrm{a}$ & $9.4 \mathrm{a}$ & $21.7 \mathrm{a}$ & $32.8 \mathrm{a}$ & $18.2 \mathrm{a}$ & $0.60 \mathrm{a}$ & $278 \mathrm{a}$ & $78.7 \mathrm{~b}$ & $70.3 \mathrm{~b}$ \\
\hline
\end{tabular}

${ }^{\mathrm{z}}$ Sprayl, Spray2, Spray3 treatments = foliar applications of $3.2,9.6$, or $16.0 \mathrm{~g} \cdot \mathrm{L}^{-1}$ urea at each spray time in 2008 and $1.6,4.8$, or $8.01 \mathrm{~g} \cdot \mathrm{L}^{-1}$ urea at each spray time in 2009 and 2010 , respectively; Ground = in Spring 2008, urea was applied at the rate of $29.6 \mathrm{~g}$ per tree in each of the two split ground applications (total of $59.2 \mathrm{~g}$ ); then two split ground applications of $34.5 \mathrm{~g}$ urea per tree (total of $69 \mathrm{~g}$ per season) were made in Spring 2009 and 2010 . Mean separation within columns by least significant difference at $5 \%$ level; $1 \mathrm{~g} \cdot \mathrm{L}^{-1}=0.1335 \mathrm{oz} / \mathrm{gal}, \mathrm{lg}=0.0353 \mathrm{oz}$.

${ }^{\mathrm{y}} 1 \mathrm{~cm}^{2}=0.1550$ inch $^{2}, 1 \mathrm{~kg}=2.2046 \mathrm{lb}, 1 \mathrm{~N}=0.2248 \mathrm{lbf}$.

${ }^{x}$ Yield in 2010 per unit trunk cross-sectional area in Feb. $2011 ; 1 \mathrm{~kg} \cdot \mathrm{cm}^{-2}=14.2233 \mathrm{lb} / \mathrm{inch}^{2}$.

With the exception of the higher fruit weight in Spray3 treatment, the effects of various $\mathrm{N}$ sprays on growth, yield, and most fruit quality attributes were not different from each other.

The total $\mathrm{N}$ application from 2008 to 2009 in the ground treatment was also slightly higher than that of the highest foliar application (Spray3). Ground-applied $\mathbf{N}$ in this experiment was at a low to medium rate that commercial growers apply to new orchards in the Pacific Northwest. Nevertheless, the portion of untaken $\mathrm{N}$ by the trees in the ground treatment was greater than the amount absorbed through the foliar applications, leading to a greater leaf $\mathrm{N}$ concentration in 2010 (Table 2), which resulted in greater tree growth, yield, and fruit size. According to the Crop Protection Guide for Tree Fruit in Washington (Washington State University, 2012), foliar applications of more than $3.6-6.0 \mathrm{~g} \cdot \mathrm{L}^{-1}$ urea to fruit trees is not recommended because of potential leaf injury. In this experiment, the highest foliar treatment per application time (Spray3) was $16.0 \mathrm{~g} \cdot \mathrm{L}^{-1}$ urea in 2008 and 8.01 $\mathrm{g} \cdot \mathrm{L}^{-1}$ urea during 2009 and 2010 (higher than the highest recommended rate). We had less number of foliar sprays during 2008 growing season than in 2009 or 2010 . We noticed very minor leaf burning along the tip of the leaves in Spray3 treatment. Thus, if we had sprayed enough $\mathrm{N}$ to supply the same amount of $\mathrm{N}$ that we did with the ground application, this would have caused phytotoxicity in the trees.

Although maximum production of high-quality fruit is the goal of any apple grower, extremely high production often results in lower fruit quality (Fallahi et al., 1985; Fallahi and Simons, 2009). It is noteworthy that in this experiment, ground $\mathrm{N}$ application increased fruit size, in spite of the yield increase compared with Sprayl and Spray 2 treatments (Table 1). Thus, ground $\mathrm{N}$ application, even at as low of a rate as used in this experiment, is more effective in early canopy establishment and production than repeated spray applications of $\mathrm{N}$ throughout the growing season. In spite of geographical and environmental differences, our results agree with Forshey (1963) who reported less vigor in 'McIntosh' trees which received foliar urea over several years as compared with those with ground application in New York.

Leaf $\mathrm{N}$ concentrations from all $\mathrm{N}$ treatments were similar in 2009
(Table 2). In 2010, however, leaf $\mathrm{N}$ increased with an increase in the total amount of $\mathrm{N}$ application because $\mathrm{N}$ treatments had more time to show their effects. Fruit color was unaffected by $\mathrm{N}$ applications (data not shown). In our evaluation, any color rating greater than a " 3 " is commercially acceptable. Fruit from all treatments, including those of ground treatment, had color ratings greater than 3.2 , thus were commercially acceptable (data not shown). None of these treatments resulted in an excessively high leaf $\mathrm{N}$ and thus did not affect the fruit skin color adversely. Ground application of $\mathrm{N}$ decreased fruit firmness both at harvest and after storage, as compared with low foliar application, perhaps due to the larger fruit size in this treatment (Table 1). Fruit SDP, SSC, and fruit water loss were unaffected by $\mathrm{N}$ treatments (data not shown).

Leaves from trees with the ground treatment had lower percent dry weights than those from all foliar treatments in 2009 and lower than those from the Sprayl and Spray2 treatments in 2010 (Table 2). Trees receiving ground $\mathrm{N}$ application had significantly lower leaf $\mathrm{K}$ but higher leaf $\mathrm{Ca}$ than those receiving foliar treatments in both

Table 2. Effects of urea nitrogen treatments on leaf percentage dry weight and mineral nutrient concentration in 'BC-Fuji' apple over 2 years. ${ }^{\mathrm{z}}$

\begin{tabular}{|c|c|c|c|c|c|c|c|c|c|c|c|c|c|c|}
\hline \multirow[b]{2}{*}{$\underline{\text { Nitrogen }}^{\mathrm{y}}$} & \multicolumn{2}{|c|}{ Leaf (\% dry wt) } & \multicolumn{2}{|c|}{$\mathrm{N}$ (\% dry wt) } & \multicolumn{2}{|c|}{$\mathrm{K}(\%$ dry wt) } & \multicolumn{2}{|c|}{$\mathrm{Ca}(\%$ dry wt) } & \multicolumn{2}{|c|}{$\mathrm{Zn}(\mathrm{ppm})^{\mathrm{x}}$} & \multicolumn{2}{|c|}{$\mathrm{Fe}(\mathrm{ppm})$} & \multicolumn{2}{|c|}{$\mathrm{Cu}(\mathrm{ppm})$} \\
\hline & 2009 & 2010 & 2009 & 2010 & 2009 & 2010 & 2009 & 2010 & 2009 & 2010 & 2009 & 2010 & 2009 & 2010 \\
\hline Sprayl & $64.0 \mathrm{a}^{\mathrm{z}}$ & $61.3 \mathrm{a}$ & $2.32 \mathrm{a}$ & $1.82 \mathrm{c}$ & $2.07 \mathrm{a}$ & $1.75 \mathrm{a}$ & $0.86 \mathrm{~b}$ & $1.12 \mathrm{bc}$ & $19 \mathrm{a}$ & $16 \mathrm{a}$ & $60 \mathrm{a}$ & $91 \mathrm{a}$ & $12 \mathrm{a}$ & $9 \mathrm{a}$ \\
\hline Spray3 & $64.0 \mathrm{a}$ & $60.3 \mathrm{ab}$ & $2.33 \mathrm{a}$ & $2.04 \mathrm{ab}$ & $2.00 \mathrm{a}$ & $1.58 \mathrm{~b}$ & $0.85 \mathrm{~b}$ & $1.19 \mathrm{~b}$ & $18 \mathrm{a}$ & $17 \mathrm{a}$ & $63 a$ & $98 \mathrm{a}$ & $11 \mathrm{~b}$ & $9 \mathrm{a}$ \\
\hline Ground & $59.7 \mathrm{~b}$ & $59.2 \mathrm{~b}$ & $2.33 \mathrm{a}$ & $2.14 \mathrm{a}$ & $1.77 \mathrm{~b}$ & $1.43 \mathrm{c}$ & $1.05 \mathrm{a}$ & $1.38 \mathrm{a}$ & $13 \mathrm{~b}$ & $14 \mathrm{~b}$ & $62 \mathrm{a}$ & $82 \mathrm{~b}$ & $8 \mathrm{c}$ & $7 \mathrm{~b}$ \\
\hline
\end{tabular}

${ }^{\mathrm{z}} \mathrm{N}=$ nitrogen, $\mathrm{K}=$ potassium, $\mathrm{Ca}=$ calcium, $\mathrm{Zn}=$ zinc, $\mathrm{Fe}=$ iron, $\mathrm{Cu}=$ copper, $\mathrm{B}=$ boron.

${ }^{y}$ Sprayl, Spray2, Spray3 treatments = foliar applications of $3.2,9.6$, or $16.0 \mathrm{~g} \cdot \mathrm{L}^{-1}$ urea at each spray time in 2008 and $1.6,4.8$, or $8.01 \mathrm{~g} \cdot \mathrm{L}^{-1}$ urea at each spray time in 2009 and 2010 , respectively; Ground $=$ in Spring 2008, urea was applied at the rate of $29.6 \mathrm{~g}$ per tree in each of the two split ground applications (total of 59.2 g); then two split applications of $34.5 \mathrm{~g}$ urea per tree (total of $69 \mathrm{~g}$ per season) were made in Spring 2009 and 2010 . Mean separation within columns by least significant difference at $5 \%$ level; $\mathrm{l} \mathrm{g} \cdot \mathrm{L}^{-1}=0.1335 \mathrm{oz} / \mathrm{gal}, \mathrm{l} \mathrm{g}=0.0353 \mathrm{oz}$.

${ }^{x} 1 \mathrm{ppm}=1 \mathrm{mg} \cdot \mathrm{kg}^{-1}$. 
Table 3. Effects of calcium sprays on mineral nutrient concentrations in some leaf and fruit tissues in 'Top Export Fuji' apple.

\begin{tabular}{|c|c|c|c|c|c|c|c|}
\hline Treatments $^{\mathrm{z}}$ & $\begin{array}{c}\text { Flesh } N^{y} \\
(\% \text { dry wt })^{x}\end{array}$ & $\begin{array}{l}\text { Flesh } \mathrm{Ca}^{\mathrm{y}} \\
(\% \text { dry wt) } \\
\end{array}$ & $\begin{array}{c}\text { Peel Ca } \\
(\% \text { dry wt })\end{array}$ & $\begin{array}{c}\text { Leaf Ca } \\
\text { (\% dry wt) }\end{array}$ & $\begin{array}{l}\text { Flesh } B^{y} \\
(p p m)^{x}\end{array}$ & $\begin{array}{l}\text { Peel B } \\
\text { (ppm) }\end{array}$ & $\begin{array}{c}\text { Flesh } \\
\text { Mo (ppm) } \\
\end{array}$ \\
\hline Control & $0.28 \mathrm{a}^{\mathrm{z}}$ & $0.027 \mathrm{~b}$ & $0.041 \mathrm{a}$ & $2.22 \mathrm{ab}$ & $18.1 \mathrm{bc}$ & $20.2 \mathrm{~b}$ & $0.21 \mathrm{~b}$ \\
\hline Chelated calcium $5 \mathrm{x}$ & $0.24 \mathrm{ab}$ & $0.030 \mathrm{a}$ & $0.047 \mathrm{a}$ & $2.03 \mathrm{~b}$ & $22.3 \mathrm{a}$ & $23.8 \mathrm{a}$ & $0.30 \mathrm{~b}$ \\
\hline $\begin{array}{l}\text { Chelated calcium } \\
4 \mathrm{x}, \mathrm{CaCl}_{2} 3 \mathrm{x}\end{array}$ & $0.23 \mathrm{~b}$ & $0.033 \mathrm{a}$ & $0.047 \mathrm{a}$ & $2.23 \mathrm{ab}$ & $18.0 \mathrm{c}$ & $19.9 \mathrm{~b}$ & $0.47 \mathrm{a}$ \\
\hline
\end{tabular}

${ }^{2}$ Control $=$ untreated control; $\mathrm{CaCl}_{2}=$ calcium chloride; Chelated calcium $5 \mathrm{x}, \mathrm{CaCl}_{2} 3 \mathrm{x}=$ chelated calcium at $0.156 \%$ was applied five times and $\mathrm{CaCl} 2$ at $0.36 \%$ three times; Chelated calcium $5 \mathrm{x}=$ chelated calcium at $0.156 \%$ was applied five times; Chelated calcium $4 \mathrm{x}, \mathrm{CaCl}_{2} 3 \mathrm{x}=$ chelated calcium at $0.156 \%$ was applied four times and $\mathrm{CaCl}$ at $0.36 \%$ three times; $\mathrm{CaCl}_{2} 3 \mathrm{x}=\mathrm{CaCl}_{2}$ at $0.36 \%$ was applied three times. Chelated calcium $=$ amino acid chelated calcium with $6 \%$ calcium $=\mathrm{Metalosate}$ Calcium $(\mathrm{Albion}$ Laboratories, Clearfield, UT). Mean separation within columns by least significant difference at $5 \%$ level.

${ }^{\mathrm{y}} \mathrm{N}=$ nitrogen; $\mathrm{Ca}=$ calcium; $\mathrm{B}=$ boron; $\mathrm{Mo}=$ molybdenum.

${ }^{\mathrm{x}} \mathrm{l} \mathrm{ppm}=1 \mathrm{mg} \cdot \mathrm{kg}^{-1} ; \mathrm{l} \mathrm{g} \cdot \mathrm{L}^{-1}=0.1 \% ; \mathrm{lg}=0.0353 \mathrm{oz}$

2009 and 2010 (Table 2). Trees with ground $\mathrm{N}$ application usually had less leaf $\mathrm{Zn}, \mathrm{Fe}$, and $\mathrm{Cu}$ than those with foliar $\mathrm{N}$ treatments (Table 2).

RESUlTS AND DISCUSSION FOR CALCIUM APPLICATIONS. Fruit flesh of trees sprayed with $\mathrm{CaCl}_{2}$ had lower $\mathrm{N}$ concentration than untreated control (Table 3 ) and the reason for this warrants further study. Applications of $\mathrm{Ca}$ in both formulations and all frequencies increased flesh Ca concentrations as compared with untreated control. There was no significant difference in the Ca concentration of peels among different treatments. With the exception of the chelated calcium $4 \mathrm{x}, \mathrm{CaCl}_{2}$ $3 \mathrm{x}$ treatment, all the other Ca treatments tended to increase flesh and peel $\mathrm{B}$ concentrations, although differences were not significant (Table 3). Five applications of chelated calcium plus $\mathrm{CaCl}_{2}$ resulted in higher leaf $\mathrm{Ca}$ than other treatments.

Fruit from all Ca treatments had lower sunburn, which is very beneficial to apple growers. There was no difference between the untreated controls and any of the Ca treatments on quality attributes and yield factors at harvest. The fact that $\mathrm{Ca}$ application tended to increase flesh $\mathrm{Ca}$ and reduce flesh $\mathrm{N}$ concentrations indicates that $\mathrm{Ca}$ application could increase fruit quality after storage, even though these differences could not be seen at harvest time.

\section{Conclusions}

A better understanding of the cuticle uptake mechanism is essential to achieve efficient foliar nutrient uptake in tree fruit. Relative humidity plays an important role in the foliar nutrient uptake and this field deserves further study. In addition to the routine applications of micronutrients, $\mathrm{N}$ and Ca can be foliary applied to improve fruit quality. However, a ground application of $\mathrm{N}$ is required as the $\mathrm{N}$ requirements of an apple tree may not solely be fulfilled through foliar $\mathrm{N}$ applications.

It appears that application of $\mathrm{Ca}$ in the form of $\mathrm{CaCl}_{2}$ could be as effective as the application of more expensive forms of $\mathrm{Ca}$ compounds but this area also deserves further investigation.

\section{Literature cited}

Blasberg, C.H. 1953. Response of mature McIntosh apple trees to urea foliar sprays in 1950 and 1951. Proc. Amer. Soc. Hort. Sci. 62:147-153.

Chaplin, M.H. and A.R. Dixon. 1974. A method for analysis of plant tissue by direct reading spark emission spectroscopy. Appl. Spectrosc. 28:5-8.

Eichert, T. and J. Burkhardt. 2001. Quantification of stomatal uptake of ionic solutes using a new model system. J. Expt. Bot. 52:771-781.

Eichert, T. and V. Fernandez. 2012. Uptake and release of elements by leaves and other aerial plant parts, p. 71-84. In: P. Marschner (ed.). Marschner's mineral nutrition of higher plants. Academic Press, Oxford, UK.

Eichert, T., A. Kurtz, U. Steiner, and H.E. Goldbach. 2008. Size exclusion limits and lateral heterogeneity of the stomatal foliar uptake pathway for aqueous solutes and water-suspended nanoparticles. Physiol. Plant. 134:151-160.

Fallahi, E., D.G. Richardson, and M.N. Westwood. 1985. Quality of apple fruit from a high density orchard as influenced by rootstocks, fertilizers, maturity, and storage. J. Amer. Soc. Hort. Sci. 110:71-74.
Fallahi, E. and B.R. Simons. 2009. Influence of fruit spacing on fruit quality and mineral partitioning of 'Redchief Delicious' apple under full crop conditions. Fruit Var. J. 47:172-178.

Fernandez, V. and T. Eichert. 2009. Uptake of hydrophilic solutes through plant leaves: Current state of knowledge and perspectives of foliar fertilization. Crit. Rev. Plant Sci. 28:36-68.

Fisher, E.G. 1952. The principles underlying foliage applications of urea for nitrogen fertilization of McIntosh' apple. Proc. Amer. Soc. Hort. Sci. 59:91-98.

Fisher, E.G. and I.A. Cook. 1950. Nitrogen fertilization of the McIntosh apple tree with leaf sprays of urea. Proc. Amer. Soc. Hort. Sci. 55:35-40.

Forshey, C.G. 1963. A comparison of soil nitrogen fertilization and urea sprays as sources of nitrogen for apple trees in sand culture. J. Amer. Soc. Hort. Sci. 83:3245 .

Franke, W. 1960. Uber die Beziehungen der Ektodesmen zur Stoffaufnahme durch die Blatter. II. Beobachtungen an Helxine soleirolii Req. Planta 55:522-541.

Franke, W. 1964. Uber die Beziehungen der Ektodesmen zur Stoffaufnahme durch die Blatter. III. Mitteilung.: Nachweis der Beteiligung der Ektodesmen an der Stoffaufnahme durch Blatter mittels radioaktiver Stoffe. Planta 61:1-64.

Jones, B.J. 1977. Elemental analysis of soil extracts and plant tissue ash by plasma emission spectroscopy. Commun. Soil Sci. Plant Anal. 8:349-365.

Khemira, H., T.L. Righetti, and A.N. Azarenko. 1998. Nitrogen partitioning in apple as affected by timing and tree growth habit. J. Hort. Sci. Biotechnol. 73:217-223.

Lovatt, C.J. 1999. Timing citrus and avocado foliar nutrient applications to increase fruit set and size. HortTechnlogy 9:607-612. 
Lovatt, C.J. and A.H. Cheng. 1990. Comparison of some aspects of nitrogen metabolism of avocado with citrus. Acta Hort. 275:489-496.

O'Kennedy, B.T., M.J. Hennerty, and J.S. Titus. 1975. The effects of autumn foliar urea sprays on storage forms of nitrogen extracted from bark and wood of apple shoots. J. Hort. Sci. 50:331-338.

Oland, K. 1960. Nitrogen feeding of apple trees by post-harvest urea sprays. Nature 185:857, (abstr.).

Peryea, F.J., D. Neilsen, and G. Neilsen. 2003. Boron maintenance sprays for apple: Early-season applications and tank-mixing with calcium chloride. HortScience 38:542-546.

Sanchez, E.E., T.L. Righetti, D. Sugar, and P.B. Lombard. 1990. Response of 'Comice' pear trees to a postharvest urea spray. J. Hort. Sci. 65:541-546.

Schonherr, J. 1976. Water permeability of isolated cuticular membranes: The effect of $\mathrm{pH}$ and cations on diffusion, hydrodynamic permeability and size of polar pores in the cutin matrix. Planta 128:113-126.

Schonherr, J. 2000. Calcium chloride penetrates plant cuticles via aqueous pores. Planta 212:112-118.

Schonherr, J. 2006. Characterization of aqueous pores in plant cuticles and permeation of ionic solutes. J. Expt. Bot. 57:2471-2491.

Schonherr, J. and M.J. Bukovac. 1970. Preferential polar pathways in the cuticle and their relationship to ectodesmata. Planta 92:189-201.

Schonherr, J. and M.J. Bukovac. 1972. Penetration of stomata by liquids: Dependence on surface tension, wettability, and stomatal morphology. Plant Physiol. 49:813-819.

Schumacher, W. and P. Lambertz. 1956. Uber die Beziehungen zwischen der Stoffaufnahme durch Blattepidermen und der Zahl der Plasmodesmen in den Aussenwanden. Planta 47:47-52.
Schuman, G.E., M.A. Stanley, and D. Knudsen. 1973. Automated total nitrogen analysis of soil and plant samples. Soil Sci. Soc. Amer. Proc. 37:480-481.

Shim, K.K., J.S. Titus, and W.E. Splittstoesser. 1972. The utilization of postharvest urea sprays by senescing apple leaves. J. Amer. Soc. Hort. Sci. 97:592-596.

Swietlik, D. and M. Faust. 1984. Foliar nutrition of fruit crops. Hort. Rev. 6:287-355.

Washington State University. 2012. Crop protection guide for tree fruit in Washington. Washington State Univ. Coop. Ext., Pullman.

Washington State University. 2013. Washington State University Tree Fruit Research and Extension Center, Wenatchee, WA. 15 May 2013. <http://www.tfrec. wsu.edu>.

Williams, R.R. 1965. The effect of summer nitrogen applications on the quality of apple blossoms. J. Hort. Sci. 40:31-41. 